УДК 669.017:621.73

Л.С. Кривчик /магістр/,

Нікопольський технікум Національної металургійної академії України, м. Нікополь, Україна

Т.С. Хохлова /к.т.н./, Національна металургійна академія України, м. Дніпро, Україна

В.Л. Пінчук

Нікопольський технікум Національної металургійної академії України, м. Нікополь, Україна

\title{
УДОСКОНАЛЕННЯ ТЕХНОЛОГІЇ ТЕРМІЧНОЇ ОБРОБКИ ПРЕСОВОГО ІНСТРУМЕНТУ ДЛЯ ПРЕСУВАННЯ НЕРЖАВЮЮЧИХ ТРУБ
}

L.S. Kryvchyk /M. Sc./,

T.S. Khokhlova /Cand. Sci. (Tech.)/,
Nikopol College of National Metallurgical Academy of Ukraine, Nikopol, Ukraine

National Metallurgical Academy of Ukraine, Dnipro, Ukraine

Nikopol College of National Metallurgical Academy of Ukraine, Nikopol, Ukraine

V.L. Pinchuk

\section{THE PERFECTION OF TECHNOLOGY OF HEAT TREATMENT OF PRESSING TOOL FOR PRESSURE RUSTPROOF PIPES}

\begin{abstract}
Мета. Метою дослідження є удосконалення технологї термічної обробки основного трубопресового інструмента - голки-оправки для пресування неіржавіючих труб на трубопрофільних пресах для подальшого вибору оптимальних режимів термозміцнення.

Методика. Для проведення дослідження з поковок діаметром 250 мм були вирізані зразки розміром $1010 \times 55$ мм $і$ піддані остаточній термічній обробиі в иехових умовах при різних температурних режимах загартування, відпуску $i$ хіміко-термічної обробки. Виготовлення мікрошліфів зводилось до виконання наступних операчій: шліфування, полірування й травлення. Проведено мікроструктурний аналіз зразків і визначена твердість після різних режимів термічної обробки.

Результати. Побудовані і досліджені графіки залежності твердості зразків від температури загартування, відпуску, запропонований оптимальний режим газового азотування (що підтверджено результатами замірів твердості) для отримання високих експлуатаційних властивостей трубопресового інструмента і отримання необхідного балу зерна, проведено дослідження структури азотованого шару (мікроструктурне і електронне). Результатом роботи є розробка оптимального режиму термозміцнення інструмента (голки-оправки) (загартування з двократним відпуском і послідуючим азотуванням замість традииійного режсим-загартування з трикратним відпуском), що підвищує міцність, зносо- і теплостійкість сталі шляхом утворення стійких у проиесі нагрівання карбідів, нітридів, боридів і т. п. В результаті сталь здобуває високу твердість на поверхні HRC 71-72, що не змінюсться при нагріванні до $400-450^{\circ} \mathrm{C}$, високу опірність зношуванню, високі гранииі витривалості, корозійну стійкість.
\end{abstract}

Наукова новизна. Вперше науково обтрунтовано вибір більи ефективного режиму термозміц-

() Кривчик Л.С., Хохлова Т.С., Пінчук В.Л., 2019 
нення трубопресового інструмента (з проведенням мікроструктурних досліджень), щзо дозволяє його використовувати в реальних умовах виробництва неіржавіючих труб на трубних підприємствах «ПрАТ Сентравіс Продакин Юкрейн», «ТОВ ВО Оскар» та ін.

Практична цінність. Удосконалення технології термічної обробки голки-оправки (загартування з відпуском і послідуючим азотуванням замість звичайної технології-загартування з відпуском) дозволить збільшити стійкість пресового інструмента на 30 \% та знизити витрати по переробці виготовлення неіржавіючих труб, а також покращчти якість внутрішньої поверхні труб (відсутність плівок, порізів та інших дефектів неіржавіючих труб).

Ключові слова: голка-оправка, пресування, термічна обробка, газове азотування, іонне азотування, загартування, відпуск, термозміцнення.

DOI: $10.34185 / 0543-5749.2019-5-6-47-56$

Вступ. Методом пресування виробляється велика кількість напівфабрикатів, виготовлених 3 чорних і кольорових металів.

Продуктивність прес-установок, якість i вартість готової продукції залежить значною мірою від виконання пресового інструменту, вартість якого становить до $25 \%$ від вартості переробки всього пресового цеху.

Пресові голки або трубні оправки - це інструмент, який утворює внутрішню порожнину труби. Під час пресування голки працюють в найбільш важких умовах, тому що піддаються розтягуючим та здавлюючим напругам при підвищеній температурі поверхневого шару внаслідок тертя металу і теплового ефекту деформації. Під час роботи відбувається подовження голки за рахунок іiї пластичної деформації, зношення її робочої поверхні, можливі обриви голок в різьбовій або робочій частині, згин або руйнування, утворення повздовжніх або поперечних тріщин, що є головними причинами порушення процесу пресування труб [1, c. 116].

Матеріал пресового інструменту повинен мати наступні властивості:

- жсароміцність - здатність зберігати міцність і пластичні характеристики при температурах обробки;

- ж⿻аростійкість - опір окисленню при тривалих нагрівах;

- розгаростійкість - здатність витримувати багатократні зміни інтенсивного нагріву i охолодження;

- зносостійкість - висока стійкість проти стирання;

- малий коефіцієнт теплового розширення для збереження постійних розмірів при нагріванні і охолодженні;

- висока теплопровідність - для швидкого відведення тепла, щоб уникнути перегріву.

Комплекс перерахованих властивостей, якими повинен володіти пресовий інструмент, досягається застосуванням при його виготовленні жароміцних сталей аустенітного і мартенситного класів, легованих хромом, вольфрамом, нікелем, молібденом; спеціальних жароміцних сплавів на основі нікелю і кобальту, що містять вольфрам, хром, молібден, титан, алюміній; твердих сплавів і мінералокерамічних матеріалів [2, с. 122].

Матеріали та методика досліджень. Пресування - високоефективний спосіб виробництва труб з високоміцних сталей і сплавів, прошивка яких на станах поперечно-гвинтової прокатки ускладнена або неможлива.

Пресовані труби характеризуються мінімальною, в порівнянні з іншими способами гарячої деформації, кількістю зовнішніх і внутрішніх дефектів завдяки найбільш сприятливій схемі напруженого стану металу у середовищі деформації (всебічне нерівномірне стиснення) [3, c. 54].

Для прошивання отвору в заготовці застосовують голки, які встановлюють у голкотримачі. Внутрішній діаметр труби визначається діаметром голки. Призначення голки - прошивання отвору в злитку й утворення отвору в трубі або профілі. Розмір голок невеликий, перебувають під дією високих температурних, силових навантажень, піддаються стиранню. 3 метою підвищення стійкості використовують внутрішне охолодження голки.

Голка (1) є формотворним технологічним інструментом, призначеним для формування внутрішнього діаметра труб. Конструкція голки для пресування труб подана на рис. 1 [3, с. 129].

Для виготовлення голок-оправок для пресування труб найчастіше використовують вториннотвердіючу безвольфрамову сталь 4Х5МФ1С, яку піддають термічній обробці [4, с. 157].

Хімічний склад сталі наведений в таблиці 1. [5, с. 145]. 

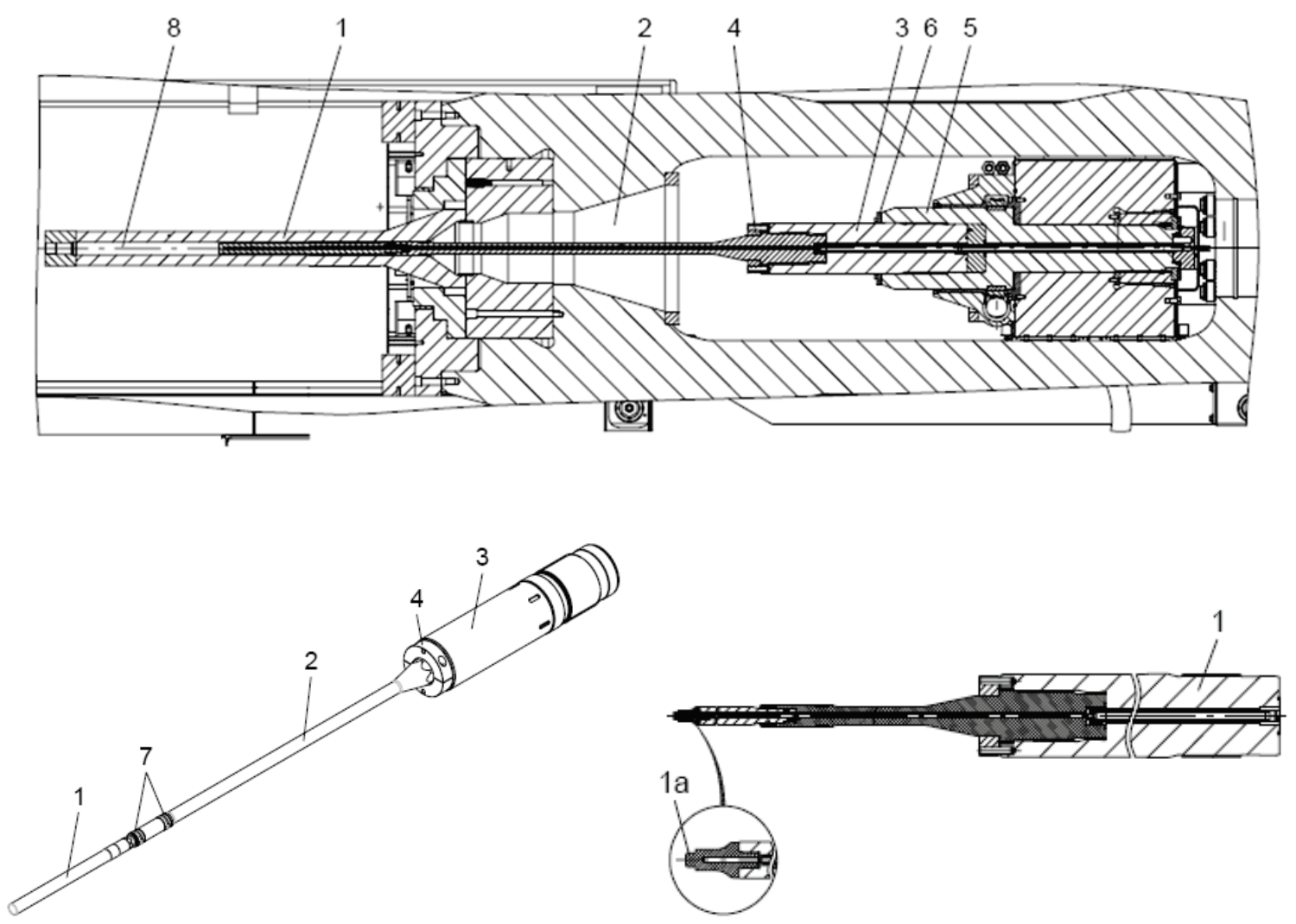

Рис. 1. Конструкція голки для пресування труб

Таблиця 1. Хімічний склад сталі 4Х5МФ1С, \% по масі (ГОСТ 5950-73)

\begin{tabular}{|c|c|c|c|c|c|c|c|c|c|}
\hline \multirow[t]{2}{*}{$\mathrm{C}$} & \multirow[t]{2}{*}{$\mathrm{Si}$} & \multirow{2}{*}{$\mathrm{Mn}$} & \multirow[t]{2}{*}{$\mathrm{Cr}$} & \multirow[t]{2}{*}{$\mathrm{V}$} & \multirow[t]{2}{*}{ Mo } & $\mathrm{Ni}$ & $\mathrm{Cu}$ & $\mathrm{S}$ & $\mathrm{P}$ \\
\hline & & & & & & \multicolumn{4}{|c|}{ не більше } \\
\hline 0,32 & 0,90 & 0,20 & 4,50 & 0,30 & 1,20 & \multirow{2}{*}{0,35} & \multirow{2}{*}{0,30} & \multirow{2}{*}{0,30} & \multirow{2}{*}{0,03} \\
\hline 0,40 & 1,20 & 0,50 & 5,50 & 0,50 & 1,50 & & & & \\
\hline
\end{tabular}

У даній роботі проведене дослідження штампової сталі 4Х5МФ1С для виготовлення голкиоправки для пресування труб на трубопрофільних пресах після різних режимів термічної обробки . Характерною рисою сталі 4Х5МФ1С $€$ комплексне легування й схильність до дисперсійного твердіння. Високий рівень легування сприятливо впливає на міцність, прогартованість, теплостійкість сталі й дає можливість використовувати іiї для інструментів, що розігріваються в процесі роботи до $600{ }^{\circ} \mathrm{C}$. Дисперсійне твердіння забезпечує гарні деформуючі властивості інструмента [6, с.56].

Проведене наступне азотування голки дозволило отримати властивості, які забезпечують не тільки якісну роботу інструмента, але й дають певний економічний ефект за рахунок зниження виробничих витрат.
Для проведення дослідження 3 поковок діаметром 250 мм були вирізані зразки розміром $10 \times 10 \times 55$ мм і піддані остаточній термічній обробці в цехових умовах. Зразки з маркованими номерами 1, 12, 24, 36, 48 загартовані в печі при температурі 950, 1000, 1050, 1070 i $1100{ }^{\circ} \mathrm{C}$. Охолодження проводилося в маслі. Зразки з номерами $60,72,84,96$ загартовано при температурі $1070{ }^{\circ} \mathrm{C}$ і піддані відпуску з різними температурними режимами. Крім того, зразки 108, 120, 132 піддані наступному азотуванню після термозміцнення.

Виготовлення мікрошліфа зводилось до виконання наступних операцій: шліфування, полірування й травлення.

Теорія та аналіз отриманих результатів. Структури зразків досліджуваної сталі, загартованих від різних температур, наведені на рис. 3 , $4,5,6$. 
Таблиця 2. Режими термообробки експериментальних зразків

\begin{tabular}{|l|c|c|c|c|c|c|}
\hline \multirow{2}{*}{$\begin{array}{c}\text { № } \\
\text { п/п }\end{array}$} & \multirow{2}{*}{ Номер } & \multirow{2}{*}{$\begin{array}{c}\text { Температура } \\
\text { загартування }\end{array}$} & \multicolumn{2}{|c|}{ Температура відпуску } & \multirow{2}{*}{$\begin{array}{c}\text { Температура } \\
\text { азотування }\end{array}$} & $\begin{array}{c}\text { Твердість } \\
\text { НRС }\end{array}$ \\
\cline { 5 - 6 } & 1. & $\mathrm{I}$ & $\mathrm{II}$ & - & $52-53$ \\
\hline 2. & 12 & $1000^{\circ} \mathrm{C}$ & - & - & - & $56-57$ \\
\hline 3. & 24 & $1050^{\circ} \mathrm{C}$ & - & - & - & $59-61$ \\
\hline 4. & 36 & $1070^{\circ} \mathrm{C}$ & - & - & - & $60-61$ \\
\hline 5. & 48 & $1100^{\circ} \mathrm{C}$ & - & - & - & $61-63$ \\
\hline 6. & 60 & $1070^{\circ} \mathrm{C}$ & $310^{\circ} \mathrm{C}-320^{\circ} \mathrm{C}$ & $300^{\circ} \mathrm{C}-310^{\circ} \mathrm{C}$ & - & $48-50$ \\
\hline 7. & 72 & $1070^{\circ} \mathrm{C}$ & $400^{\circ} \mathrm{C}-420^{\circ} \mathrm{C}$ & $380^{\circ} \mathrm{C}-400^{\circ} \mathrm{C}$ & - & $51-52$ \\
\hline 8. & 84 & $1070^{\circ} \mathrm{C}$ & $530^{\circ} \mathrm{C}-550^{\circ} \mathrm{C}$ & $500^{\circ} \mathrm{C}-530^{\circ} \mathrm{C}$ & - & $52-53$ \\
\hline 9. & 96 & $1070^{\circ} \mathrm{C}$ & $550^{\circ} \mathrm{C}-570^{\circ} \mathrm{C}$ & $530^{\circ} \mathrm{C}-550^{\circ} \mathrm{C}$ & - & $54-55$ \\
\hline 10. & 108 & $1070^{\circ} \mathrm{C}$ & $550^{\circ} \mathrm{C}-570^{\circ} \mathrm{C}$ & $530^{\circ} \mathrm{C}-550^{\circ} \mathrm{C}$ & $500^{\circ} \mathrm{C}-520^{\circ} \mathrm{C}$ & $71-72$ \\
\hline 11. & 120 & $1070^{\circ} \mathrm{C}$ & $550^{\circ} \mathrm{C}-570^{\circ} \mathrm{C}$ & $530^{\circ} \mathrm{C}-550^{\circ} \mathrm{C}$ & $540^{\circ} \mathrm{C}-560^{\circ} \mathrm{C}$ & $68-69$ \\
\hline 12. & 132 & $1070^{\circ} \mathrm{C}$ & $550^{\circ} \mathrm{C}-570^{\circ} \mathrm{C}$ & $530^{\circ} \mathrm{C}-550^{\circ} \mathrm{C}$ & $580^{\circ} \mathrm{C}-600^{\circ} \mathrm{C}$ & $66-67$ \\
\hline
\end{tabular}

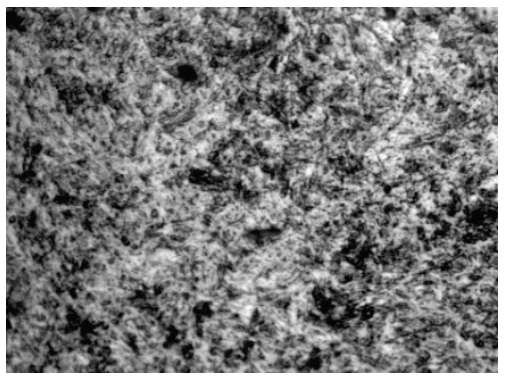

Рис. 3. Мікроструктура сталі 4Х5МФ1С після загартування від $950{ }^{\circ} \mathrm{C}$ (мартенсит мілко-голчастий, аустеніт остатній і карбіди), $* 500$

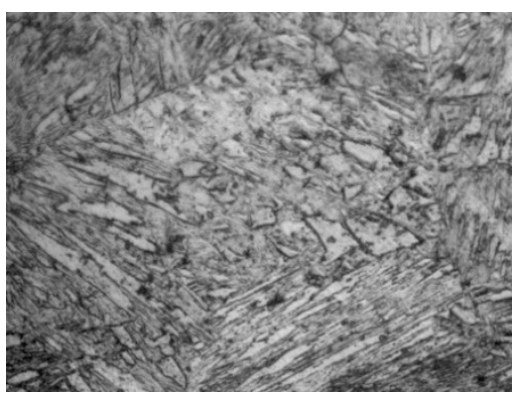

Рис. 5. Мікроструктура сталі 4Х5МФ1С після загартування від $1070{ }^{\circ} \mathrm{C}$ (мартенсит голчастий, аустеніт остатній і карбіди), *500

Дослідження сталі 4Х5МФ1С показали, що зі збільшенням температури загартування збільшується твердість (рис. 7), тому що аустеніт (мартенсит після охолодження) стає більш легованим за рахунок розчинення карбідів при

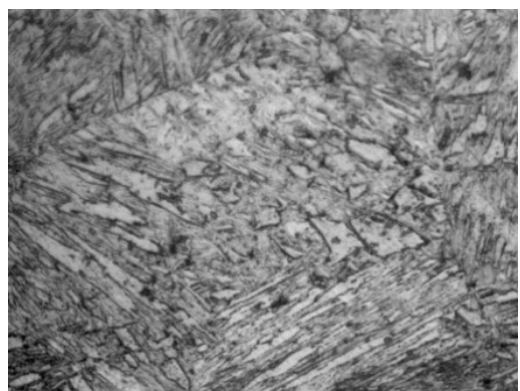

Рис. 4. Мікроструктура сталі 4Х5МФ1С після загартування від $1050{ }^{\circ} \mathrm{C}$ (мартенсит голчастий, аустеніт остатній і карбіди), $* 500$

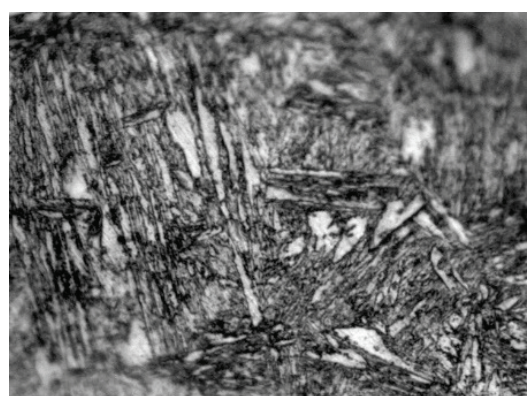

Рис. 6. Мікроструктура сталі 4Х5МФ1С після загартування від $1100^{\circ} \mathrm{C}$ (мартенсит крупно-голчастий, аустеніт остатній і карбіди), *500

нагріванні.

Структури зразків досліджуваної сталі, загартованих від температури $1070{ }^{\circ} \mathrm{C}$ і відпущених при різних температурах, наведені на рис. 8, 9, 10 . 


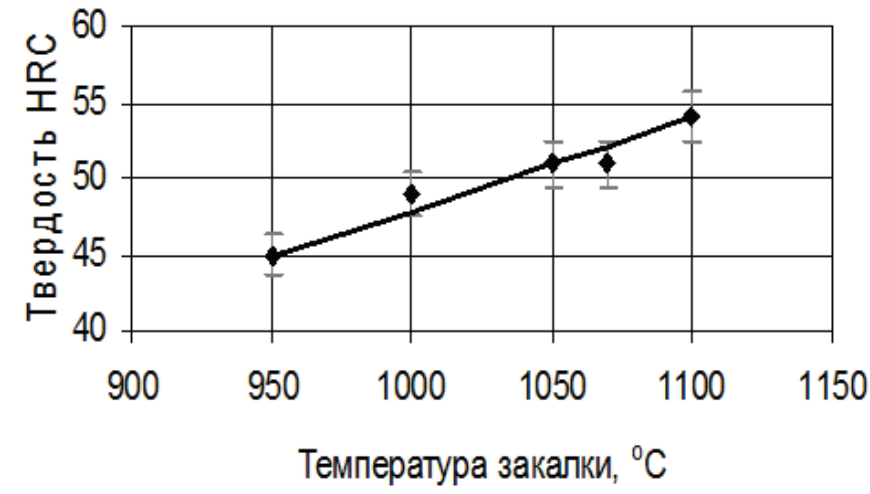

Рис. 7. Залежність твердості загартованих зразків сталі 4Х5МФ1С від температури загартування

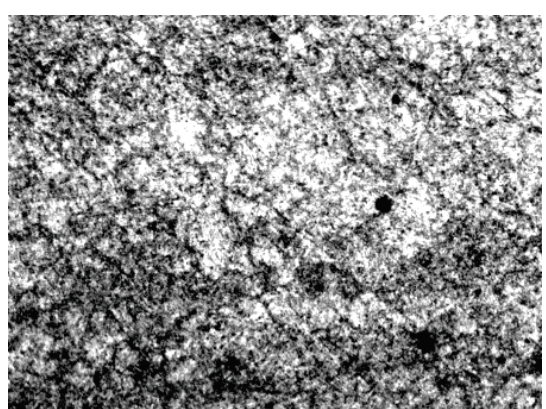

Рис. 8. Мікроструктура сталі 4Х5МФ1С після загартування від $1070^{\circ} \mathrm{C}$ і відпущеної при $400^{\circ}-420^{\circ} \mathrm{C}\left(1\right.$ відпуск), $380^{\circ}-400^{\circ} \mathrm{C}$ (2 відпуск) (троостит відпуску), *500

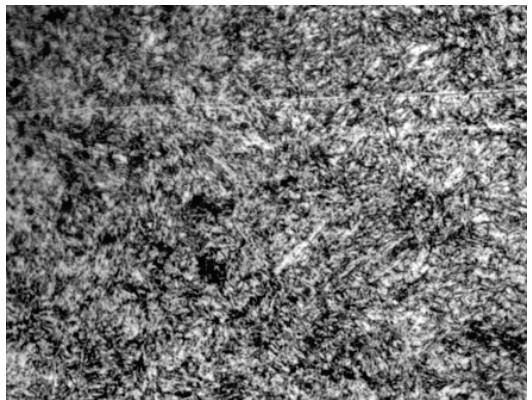

Рис. 9. Мікроструктура сталі 4Х5МФ1С після загартування від $1070{ }^{\circ} \mathrm{C}$ і відпущеної при $530^{\circ}-550^{\circ} \mathrm{C}\left(1\right.$ відпуск), $500^{\circ}-530^{\circ} \mathrm{C}$ (2 відпуск) мартенсит відпущений та карбіди), *500

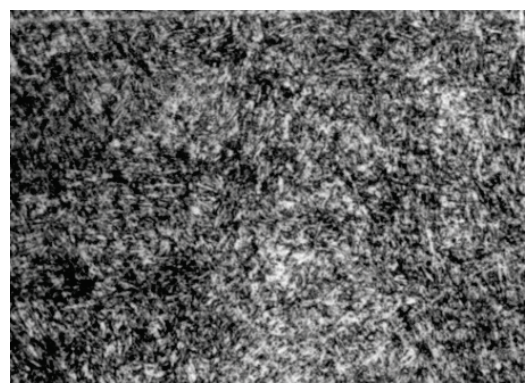

Рис. 10. Мікроструктура сталі 4 Х5МФ1С після загартування від $1070{ }^{\circ} \mathrm{C}$ і відпущеної при $550^{\circ}-570{ }^{\circ} \mathrm{C}$ (1 відпуск), $530^{\circ}-550^{\circ} \mathrm{C}$ (2 відпуск) (мартенсит відпущений та карбіди), *500

Видно, що відпуск при $300-350^{\circ} \mathrm{C}$ знижує твердість через виділення з мартенситу цементитного карбіду. Відпуск при температурах порядку $500-550^{\circ} \mathrm{C}$ створює вторинну твердість, внаслідок дисперсійного твердіння. У молібденових сталях на цій стадії виділяються карбіди $\mathrm{Me}_{23} \mathrm{C}$ и $\mathrm{Me}_{6} \mathrm{C}$. При подальшому підвищенні температури підсилюється коагуляція карбідів, що веде до зниження твердості [6, c.112].

Залежність твердості сталі від температури відпуску показано на рис. 11.

Зносостійкість інструментальної сталі, тобто здатність ії протистояти різним видам зношування поверхні, є характеристикою довговічнос- ті інструмента. Зношування супроводжується не тільки фізичним руйнуванням робочого шару й втратою маси металу, але і його пластичним деформуванням. У результаті обох процесів змінюються форма й розміри робочих крайок $[8$, c. 144].

Таким чином, зносостійкість дуже складна властивість. Вона визначається не тільки хімічним складом, структурою й механічними властивостями, але й властивостями оброблюваного матеріалу, умовами експлуатації інструмента, його конструкції і т. д. Останні визначають характер зношування: абразивний, адгезійний, ерозійний, дифузійний і ін. [9, с. 136]. 


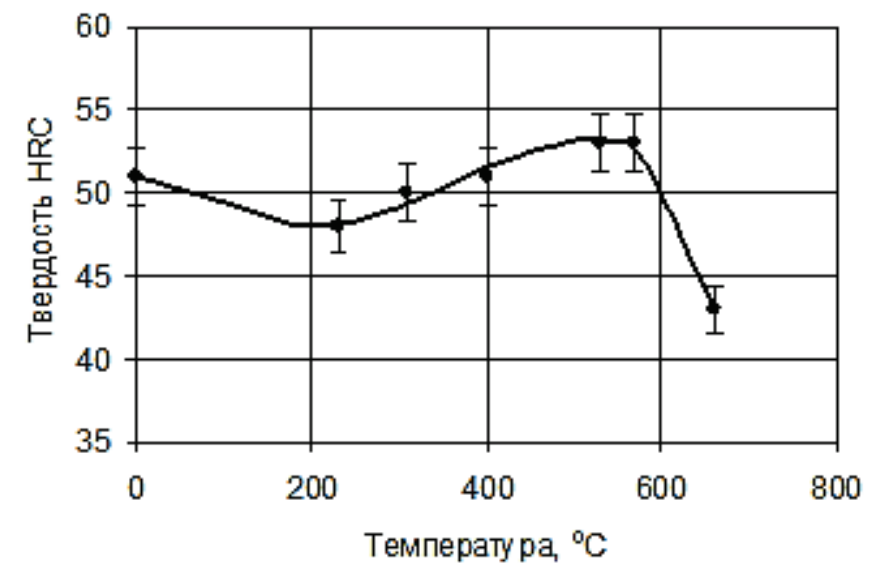

Рис. 11. Залежність твердості сталі 4Х5МФ1С від температури відпуску

3 причини росту аустенітного зерна зі збільшенням температури знижується в'язкість сталі, то відповідно до ДЕРЖСТАНДАРТУ 5950 - 2000 для сталі 4Х5МФ1С розмір аустенітного зерна не повинен перевищувати 8 балів. Більш кращою для загартування є температура $1070{ }^{\circ} \mathrm{C}$, тому що в цьому випадку унеможливлюється можливість перегріву сталі (бал аустенітного зерна 9).

Ефективним способом зміни складу поверхневого шару штампового інструмента, що забезпечують необхідний комплекс властивостей його робочої поверхні, є хіміко-термічна обробка. У результаті змінюються структура й властивості поверхневого шару, підвищуються міцність, зносо- і теплостійкість сталі шляхом утворення стійких у процесі нагрівання карбідів, нітридів, боридів і т. п. [10, с. 64].

Найпоширеніше зміцнення поверхні голокоправок азотуванням, у результаті якого сталь здобуває високу твердість на поверхні, що не змінюється при нагріванні до $400-450{ }^{\circ} \mathrm{C}$, високу опірність зношування, високі границі витривалості, корозійну стійкість. Структура, глибина й властивості азотованого шару залежать від хімічного й фазового складу сталі, а також від режимів азотування, які визначаються методом, температурою й тривалістю процесу [11, c. 67].

В основному в промисловості використовують різні процеси низькотемпературного азотування ( при температурі $500-600^{\circ} \mathrm{C}$ ), що створюють високу твердість поверхні.

Низькотемпературне азотування проводять у газових або рідких середовищах. Низька температура процесу $\left(500-600{ }^{\circ} \mathrm{C}\right)$ пов'язана $з$ необхідністю отримати високу твердість поверхневого шару. На відміну від поверхневого загартування й цементації, при яких зміцнення досягається в результаті мартенситного перетворен- ня, при азотуванні висока твердість поверхневого шару створюється за рахунок утворення дисперсних нітридів (особливо легуючих елементів), і азотистого твердого розчину, що супроводжується ростом мікронапруг. Підвищення температури процесу створює умови для коагуляції нітридів, при цьому твердість знижується. Через низьку температуру процес низькотемпературного азотування досить тривалий, особливо при його здійсненні в газових середовищах. У рідких середовищах і особливо при іонному азотуванні (у тліючому розряді) процес насичення значно прискорюється [13, с. 15, 14, с.156].

Газове азотування здійснювалось в шахтних герметизованих печах типу США або в камерних (ковпакових) печах. Технологічними параметрами процесу азотування є температура й тривалість насичення, склад і кількість поданих газів, ступінь дисоціації аміаку (обумовлена температурою процесу й швидкістю його подачі) $[12$, с. 168$]$.

Значне (до 2 раз) прискорення азотування досягається при введенні в аміачно-водневу атмосферу кисню (4 л на 100 л аміаку), повітря, вуглекислого газу і їх сумішей.

Деталі після азотування слід прохолоджувати до $150-250{ }^{\circ} \mathrm{C}$ у печі або під муфелем при безперервній подачі аміаку.

Необхідні властивості пресового інструмента HRC44...51, KCU = 30...45 Дж/см² забезпечуються структурою троостита 3 карбідною неоднорідністю не більш 4 балу по шкалі 5 ДЕРЖСТАНДАРТ 801 [9, с. 185].

Після проведення азотування голки азотований шар на поверхні складається 3 нітридної зони $\mathrm{Fe}_{23} \mathrm{~N}$ ( $\varepsilon$-фаза) і $\mathrm{Fe}_{4} \mathrm{~N}$ ( $\gamma^{\prime}$-фаза) і підшару азотистого фериту ( $\alpha$-фаза), в якому при охолодженні виділяються нітриди хрому, молібдену, алюмінію (рис. 12, 13). Графік термічної обробки голки наведений на рис. 14. 


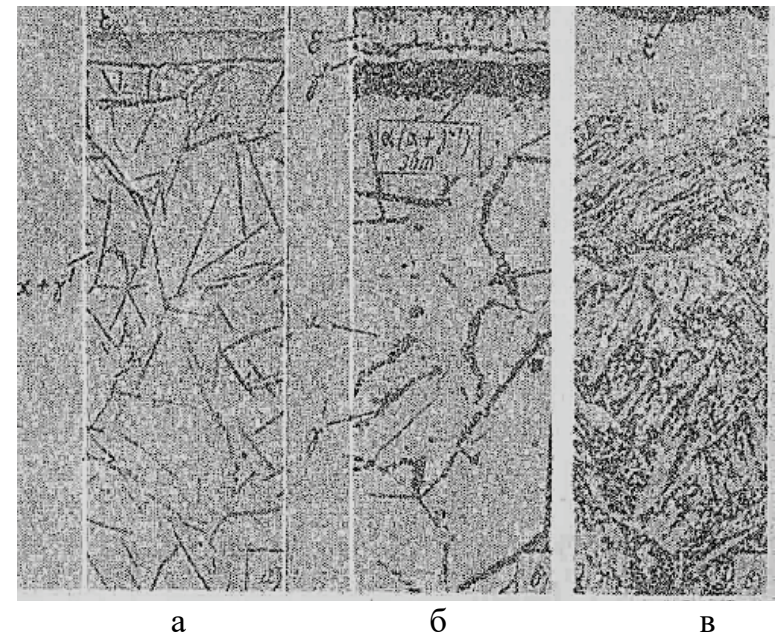

на залізі (а і б), ×600 і сталі 4Х5МФ1С, ×1000 (в)

Рис. 12. Мікроструктура азотованого шару [10, с. 114]

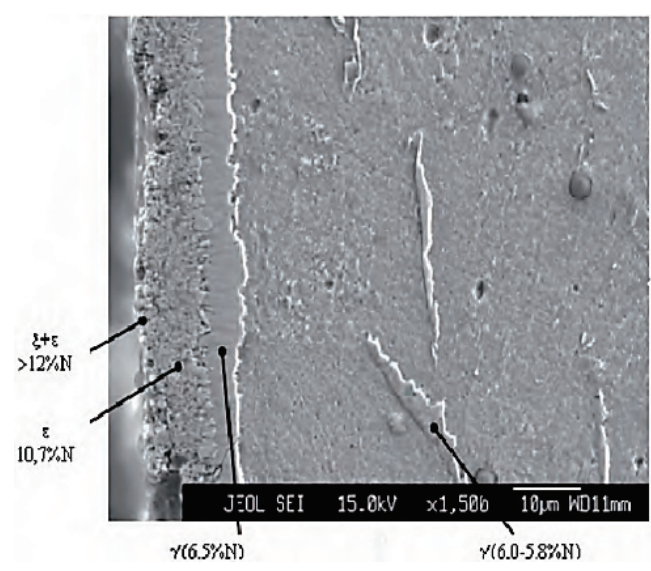

Рис. 13. Азотований шар при електронному дослідженні, *1500, [11, с. 95]

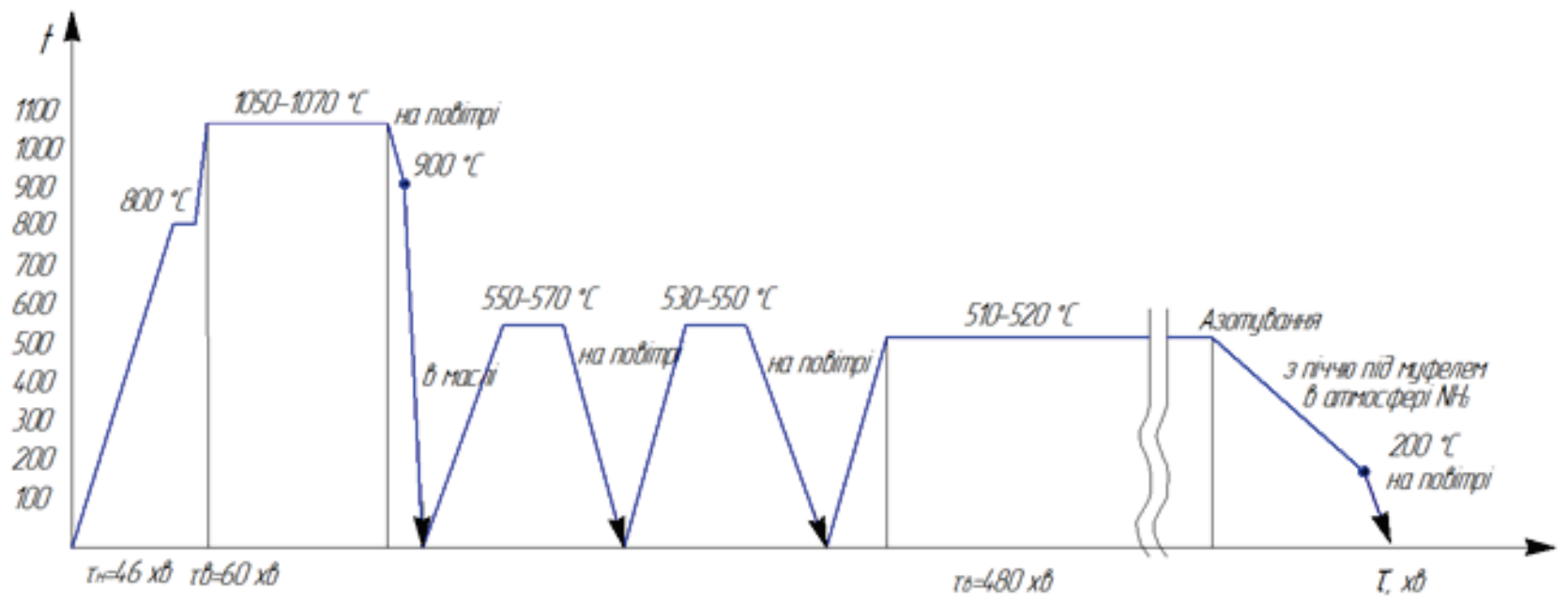

Pис. 14. Графік термічної обробки голки-оправки зі сталі 4Х5МФ1С

В заводських умовах традиційна технологія термозміцнення голок представляє собою загартування 3 наступним трикратним відпуском для отримання твердості $54-55$ HRC. Запро- понована технологія термозміцнення виключає третій відпуск і додатково використовує азотування голок з метою зміни структури й властивостей поверхневого шару, підвищення міцнос- 
ті, зносо- і теплостійкості сталі шляхом утворення стійких у процесі нагрівання карбідів, нітридів, боридів і т. п.

В результаті сталь здобуває високу твердість на поверхні HRC 71 - 72, що не змінюється при нагріванні до $400-450{ }^{\circ} \mathrm{C}$, високу опірність зношуванню, високі границі витривалості, корозійну стійкість.

Висновки. 1. Удосконалення технології термічної обробки голки-оправки (загартування 3 відпуском і послідуючим азотуванням замість звичайної технології - загартування 3 відпуском) дозволить збільшити стійкість пресового інструменту на $30 \%$ та знизити витрати по переробці виготовлення труб, а також покращити якість внутрішньої поверхні труб (відсутність плівок, порізів та інших дефектів неіржавіючих труб).

2. Використання іонного азотування в плазмі тліючого розряду значно скорочує загальний час процесу (в $2-3$ рази) і підвищує якість азотованої зони.

\section{Бібліографічний список}

1. Гуляев Г. И., Притоманов А. Е., Дробич О. П., Верховод В. К. Прессование стальных труб и профилей : учебник. Москва : Металлургия, 1973. $192 \mathrm{c.}$

2. Геллер Ю. А. Инструментальные стали. Москва : Металлургия, 1968. 568 с.

3. Шерба В. Н., Райтбарг Л. Х. Технология прессования металлов. Москва : Металлургия, $1995.153 \mathrm{c}$.

4. Гуляев А.П. Металловедение : Учебник для вузов / А.П. Гуляев. - М.: Металлургия, 1986. $-542 \mathrm{c}$.

5. Позняк Л. А., Скрынченко С. И. Штамповые стали. Москва : Металлургия, 1980. 244 с.

6. Артингер И. Инструментальные стали и их термическая обработка. Москва : Металлургия, $1982.312 \mathrm{c.}$

7. Манегин Ю. В., Притоманов А. Э., Шмиттель Т. Горячее прессование труб и профилей. Москва : Металлургия, 1980. 272 с.

8. Металловедение и термическая обработка стали: справочник. Т. 1. Методы испытаний и исследования / под ред. М. Л. Бернштейна, А. Г. Рахштадта. - Москва: Металлургия, 1983. $367 \mathrm{c}$.

9. Башнин Ю. А., Ушаков Б. К., Секей А. Г. Технология термической обработки стали. Москва : Металлургия, 1986. 386 с.

10. Химико-термическая обработка металлов и сплавов : справочник / под ред. Л. С. Ляховича. Москва : Металлургия, 1981. 420 с.
11. Александров В. А., Богданов К. В. Азотирование инструмента из высокохромистых и быстрорежущих сталей. Упрочняющие технологии и покрытия. 2005. № 5. С. 14-20.

12. Масленков С. Б., Масленкова Е. А. Стали и сплавы для высоких температур. Кн. 1. Москва : Металлургия, 1991. 383 с.

13. Арзамасов Б. Н., Братухин А. Г., Елисеев Ю. С., Панайоти Т. А. Ионная химикотермическая обработка сплавов в газовых средах. Москва: МГТУ им. Н.Э. Баумана, 1999. $400 \mathrm{c}$.

14. Новые идеи о механизме образования структуры азотированных сталей / С.А. Герасимов и др. МиТОМ. 2004. №1. С. 13-17.

\section{References}

1. Guliaev, G. I., Pritomanov, A. E., Drobich, O. P., \& Verkhovod, V. K. (1973). Pressovanie stalnykh trub i profilei. Moskva: Metallurgiia.

2. Geller, Iu. A. (1968). Instrumentalnye stali. Moskva: Metallurgiia.

3. Sherba, V. N., \& Raitbarg, L. Kh. (1995). Tekhnologiia pressovaniia metallov. Moskva: Metallurgiia.

4. Guliaev, A. P. (1986). Metallovedenie. Moskva: Metallurgiia.

5. Pozniak, L. A., \& Skrynchenko, S. I. (1980). Shtampovye stali. Moskva: Metallurgiia.

6. Artinger, I. (1982). Instrumentalnye stali $i$ ikh termicheskaia obrabotka. Moskva: Metallurgiia.

7. Manegin, Iu. V., Pritomanov, A. E., \& Shmittel, T. (1980). Goriachee pressovanie trub $i$ profilei. Moskva: Metallurgiia.

8. Bernshtein, M. L., \& Rakhshtadt, A. G. (Eds.). (1983). Metallovedenie i termicheskaia obrabotka stali. Vol. 1. Metody ispytanii i issledovaniia. Moskva: Metallurgiia.

9. Bashnin, Iu. A., Ushakov, B. K., \& Sekei, A. G. (1986). Tekhnologiia termicheskoi obrabotki stali. Moskva: Metallurgiia.

10. Liakhovich, L. S. (1981). Khimikotermicheskaia obrabotka metallov i splavov. Moskva: Metallurgiia.

11. Aleksandrov, V. A., \& Bogdanov, K. V. (2005). Azotirovanie instrumenta iz vysokokhromistykh i bystrorezhushchikh stalei. Uprochniaiushchie tekhnologii i pokrytiia, (5), 14-20.

12. Maslenkov, S. B., \& Maslenkova, E. A. (1991) Stali $i$ splavy dlia vysokikh temperatur. Vol. 1. Moskva: Metallurgiia.

13. Arzamasov, B. N., Bratukhin, A. G., Eliseev, Iu. S., \& Panaioti, T. A. (1999). Ionnaia khimiko-termicheskaia obrabotka splavov v gazovykh sredakh. Moskva: MGTU im. N. E. Baumana. 
14. Gerasimov, S. A. et al. (2004). Novye idei o mekhanizme obrazovaniia struktury azotirovannykh stalei. MiTOM, (1), 13-17.

Цель. Целью исследования является усовершенствование технологии термической обработки основного трубопрессового инструмента - игль-оправки для прессования нержавеющих труб на трубопрофильных прессах для дальнейшего выбора оптимальных режимов термоупрочнения.

Методика. Для проведения исследования с поковок диаметром 250 мм были вырезаны образиы размером $1 \otimes 10 \times 55$ мм и подвергнуты окончательной термической обработке в иеховых условиях при разных температурных режимах закалки, отпуска и химикотермической обработки. Изготовление микрошлифов сводилось к выполнению следующих операчий: шлифование, полирование и травление. Проведено микроструктурный анализ образиов и определена твердость после разных режимов термической обработки.

Результаты. Построены и исследованы графики зависимости твердости образиов от температуры закалки, отпуска, предложенный оптимальный режим газового азотирования (что подтвердилось результатами замеров твердости) для получения высоких эксплуатационных свойств трубопрессового инструмента и получения необходимого балла зерна, проведено исследование структуры азотированного слоя (микроструктурное и электронное). Результатом работь есть разработка оптимального режима термоупрочнения инструмента (игль-оправки) (закалка с двухкратным отпуском и последуюшим азотированием вместо традиционного режима - закалки с трехкратным отпуском), что повышает прочность, износо- и теплостойкость стали путем образования стойких в проиессе нагревания карбидов, нитридов, боридов и т.д. В результате сталь приобретает высокую твердость на поверхности HRC 71-72, которая не изменяется при нагревании до $400-500{ }^{\circ} \mathrm{C}$, высокое сопротивление изнашиванию, высокие границы долговечности, коррозионную стойкость.

Научная новизна. Впервые научно обоснованный выбор более эффективного режима термоупрочнения трубопрессового инструмента (с проведением микроструктурных исследований), что позволяет его использовать в реальных условиях производства нержавеющих труб на трубных предприятиях «ЧАО Сентравис Продакшн Юкрейн», «ООО ПО Оскар» и др.
Практическая ценность. Усовершенствование технологии термической обработки игль-оправки (закалка с отпуском и последующим азотированием вместо обычной технологии - закалки с отпуском) позволит увеличить стойкость прессового инструмента на $30 \%$ и уменьшить расходы по переделу при изготовлении нержавеющих труб, а также улучшить качество внутренней поверхности труб (отсутствие пленок, порезов и других дефектов нержавеющих труб).

Ключевые слова: игла-оправка, термическая обработка, газовое азотирование, ионное азотирование, закалка, отпуск, термоупрочнение.

Purpose. The aim of the study is to improve the technology of heat treatment of the main pipepress tool - needle-mandrel intended for pressing corrosion-proof pipes on pipe-shaped presses for further selection of the optimum modes of thermal strengthening.

Methods. For this research specimens of size $10 \times 10 \times 55 \mathrm{~mm}$ were cut from $250 \mathrm{~mm}$ diameter forgings and subjected to final heat treatment at different temperatures of tempering, tempering and chemical-thermal treatment in workshop conditions. The production of micro sanding was reduced to the following operations: grinding, polishing and etching. The microstructural analysis of the samples was carried out and the hardness after different heat treatment modes was determined.

Results. Graphs of hardness dependence of samples on temperature of tempering and release are constructed and investigated, the optimal mode of gas nitriding is proposed (which is confirmed by the results of hardness measurements) to obtain high performance properties of the pipe press tool and to obtain the required grain score, the structure of the nitrated layer (microstructural and electronic) was investigated. The result of the work is the development of the optimal mode of thermal strengthening of the tool (needle-mandrel) (double-tempering and subsequent nitriding instead of traditional mode- three-tempering), which increases the strength, endurance and heat resistance of steel by the formation of carbides, nitrides, borides and the like in the process of heating. As a result, the steel has a high hardness on the surface of HRC 71-72, which does not change when heated to $400-450{ }^{\circ} \mathrm{C}$, high wear resistance, high endurance limits, corrosion resistance.

Originality. For the first time, the choice of a 
more effective mode of thermal strengthening of the pipe-press tool is scientifically substantiated (with the help of microstructural studies) that allows it to be used in the real world of corrosionproof pipes production at the pipe companies of "PJSC Centravis Production Ukraine», «LLC OO Oscar» and others.

Practical implications. The perfection of the needle-mandrel heat treatment technology (tempering with tempering and subsequent nitriding instead of conventional technology of tempering with tempering) will increase the resistance of the press tool by $30 \%$ and reduce the cost of processing the manufacture of stainless steel pipes, as well as can improve the quality of the inner surface of the pipes (absence of pellicles, cuts and other defects of corrosion-proof pipes).

Key words: needle-mandrel, pressing, heat treatment, gas nitriding, ion nitriding, tempering, release, thermal strengthening.

Рукопис надійшов 11.11.2019 